\title{
Religion and African Civil Wars
}

\author{
Niels Kastfelt, ed. \\ New York: Palgrave MacMillan, 2005. 203 pages.
}

This volume contains an introduction and seven case studies by anthropologists, historians, and theologians. The papers were originally presented at a 1999 conference on "Religion and Social Upheaval in Africa" in Denmark. As a result, some of the papers are somewhat out-of-date, although the questions they raise are, sadly, just as relevant as ever to the continent's current situation.

As Niels Kastfelt points out in his introductory essay, the authors reject any approach that seeks to understand African civil conflicts in terms of a "New Barbarism," an irrational manifestation of "tribal" or religious atavism. This strategy, which is perhaps most typical of journalistic accounts but also finds some support among academics, clearly constitutes an obstacle toward any meaningful comprehension of the phenomena in question. In a similar vein, they equally reject any notion of a "conflict of civilizations" or that African civil wars can be explained in terms of the incompatible religious values of Christianity, Islam, and indigenous African religions. Rather, their papers provide a detailed account of the local context in a historical perspective by focusing on the political, economic, and explicitly religious phenomena.

Indeed, the lines of cleavage in many of these cases are not defined in religious terms. As a result, the nature of the relationships between "religion" and the civil wars in question are so disparate that the volume does not quite hang together. For example, René Devisch's paper on Kinshasa is not really about civil war, but rather about the effects of the collapse of state authority and the formal economy, both of which unleashed rampant violence in the city but also led to the emergence of independent Christian healing communes as a sort of refuge. 
Conversely, Paul Richards' paper on Sierra Leone's RUF (Revolutionary United Front) as a millennarian sect, while clearly about civil war, is only about "religion" if one defines the term so broadly that it loses all analytical specificity. Explicitly adopting a neo-Durkheimian approach pioneered by Mary Douglas, he argues that the movement's ideology is structured by the pervasiveness of isolated egalitarian groups of very young recruits awaiting an apocalyptic renewal of society through the systematic demolition of state structures. Aside from its obligatory morning prayers, where all participants are required to recite the Lord's Prayer and Surat al-Fatihah and sing the RUF anthem (and brutally beaten for any omissions), it is difficult to categorize the movement as "religious" in any conventional sense.

If the other papers all discuss the relationship of religion to civil war at all, they do so in radically different ways. Timothy Longman analyzes the Catholic Church's silence, if not complicity, in the face of massacres in Rwanda and Burundi. He suggests that this is a continuation of a colonialperiod pattern of relying upon and complying with state authorities. Kordt Højberg, on the other hand, argues that the Loma's violence against a Muslim Mandingo minority in the border region between Liberia, Guinea, and Sierra Leone is not a manifestation of deep cultural patterns connected with the masking rituals of secret societies. Rather, he suggests that the political use of religious symbols in these cases represents a new phenomenon, one explicable in terms of current political and economic struggles instead of in terms of an atavistic and uncontrolled return to the past. Andrew Wheeler documents the Christianization of southern Sudan during the civil war through a series of narratives that illustrate the convergence of different trajectories in different local contexts.

Sharon Hutchinson's account of the Nuer and the Dinka in the Sudanese civil wars and David Maxwell's analysis of Katetere chiefdom in Zimbabwe during and after the war of liberation are the most complex and, in many respects, the most successful papers. Hutchinson examines the effects of a split in the southern Sudanese leadership that led to horrendous internecine violence and triggered different religious responses among different categories of actors: the rebel leadership remained steadfastly secularist, the rank and file increasingly turned to indigenous prophets for spiritual protection, and the civilian population underwent mass conversion to Christianity. These conversions pose new sorts of problems, given the proliferation of rival Christian sects, many of which seek to bolster their membership by serving as channels for refugee aid provided by various Christian NGOs.

Maxwell discusses how generational conflicts in Katerere chiefdom are articulated with the changing political and economic landscape in Zimbabwe 
to yield competing religious movements: mission churches and spirit mediumship, under gerontocratic control, are increasingly challenged by the proliferation of Pentecostal churches alongside a rash of witchcraft accusations. This kind of fine-grained analysis of competing religious movements and orientations within specific local contexts is essential to understanding religion in modern Africa, whether during times of civil war or peace.

Precisely because these are individual case studies that do revolve around very different facets of the relationship between war and religion, the volume hardly lends itself to a coherent comparative perspective. In this respect, it is unfortunate that the volume contains no detailed case studies of Muslim responses to civil war, although it is clear that the wars in Sudan, Sierra Leone, and Liberia all involve large numbers of Muslims. Does the pervasiveness of Christian sectarianism lead to different sorts of responses to war among Christians than among Muslims and, if so, under what conditions? When does civil war lead to a revival of indigenous African religion, and when does it accelerate its marginalization? However interesting the case studies in this volume are, it is hardly able to begin to address such questions. 